\title{
Does biomass production depend on plant community diversity?
}

\author{
Maria Ivanilda de Aguiar • Jamili Silva Fialho • \\ Francisco das Chagas Silva de Araújo • Mônica Matoso Campanha • \\ Teógenes Senna de Oliveira
}

Received: 17 July 2012/Accepted: 5 December 2012/Published online: 21 December 2012

(C) Springer Science+Business Media Dordrecht 2012

\begin{abstract}
In order to ensure the sustainability of agroecosystems, biodiversity must be a priority. Agroforestry, which includes trees, is an example of such diverse systems. We evaluated plant diversity and aboveground biomass production to assess whether areas under fallow following traditional cultivation return to their initial condition. Also, plant diversity and aboveground biomass production were assessed in agroforestry systems (AFS) to determine if these were similar to unmanaged ecosystems. Another objective of the study was to observe the influence of plant diversity on aboveground biomass production in plant communities and also in the population of the dominant species, Cordia oncocalyx. Plant diversity was evaluated by
\end{abstract}

M. I. de Aguiar $(\bowtie)$ J. S. Fialho ·

F. C. S. de Araújo - T. S. de Oliveira

Departamento de Ciências do Solo, Universidade Federal

do Ceará (UFC), PICI Campus, Bloc 807, Fortaleza,

CE 60455-760, Brazil

e-mail: ivanildaaguiar@yahoo.com.br

M. I. de Aguiar

Instituto Federal de Educação Ciência e Tecnologia do

Piauí, Corrente, PI 64980-000, Brazil

J. S. Fialho

Faculdade de Educação, Ciências e Letras do Sertão

Central, Universidade Estadual do Ceará, Quixadá,

CE 69000-000, Brazil

M. M. Campanha

Empresa Brasileira de Pesquisa Agropecuária-CNPCO,

Sobral, CE 62010-970, Brazil assessing species richness, as well as using Shannon's $\left(\mathrm{H}^{\prime}\right)$ and Pielou's $\left(\mathrm{J}^{\prime}\right)$ indices. Aboveground plant biomass was evaluated in two AFS: agrosilvopastoral (ASP) and silvopastoral (SP), and also in a traditionally managed agricultural system (AG), areas that had been under fallow for six years (F6) and nine years (F9) and an area of unmanaged caatinga (CAT) vegetation. We observed that the ASP system had a lower diversity and number of species, especially tree species. However, it sustained the same total biomass production as CAT and fallow areas. The SP system, despite having lower $\mathrm{H}^{\prime}$ and $\mathrm{J}^{\prime}$ indices as well as lower total biomass production, had a similar number of species to CAT and cropped and fallow systems AG, F6 and F9. Plant biomass in F6 and F9 had recovered to productivity levels of unmanaged CAT vegetation; however the diversity indices were not restored to the same level. Plant diversity did not have an effect on the productivity of the agroecosystems. Likewise, annual biomass production by $C$. oncocalyx is not dependent upon diversity, but it is influenced by the growth stage of individuals.

Keywords Agroecology · Diversity index · Agroforestry systems $\cdot$ Semiarid

\section{Introduction}

Several authors studied diversity taking into consideration its economic value and its influence on the 
efficient functioning of ecosystems (Smukler et al. 2010; Swift et al. 2004; Tilman et al. 2005). In these studies, one of the most widely used parameter to evaluate the functioning of ecosystems is biomass productivity. According to Lehman and Tilman (2000), as plant diversity increases, the productivity of the community also increases, although there is a possibility of reduction in the productivity of individual species.

Field experiments performed with annual plants showed that the beneficial effect of diversity on productivity makes communities more efficient in their use of resources, primarily soil nutrients, and thus heterogeneous communities are more productive than monocultures (Smith et al. 2008; Tilman and Pacala 1993). Tilman et al. (2005) noted that a local reduction in diversity can lead to reduced ecosystem productivity and compromise stability over time. Greater diversity may lead to greater efficiency in the use of limited resources (Wilsey and Potvin 2000; Keer and Zedler 2002; Tilman et al. 2005), and greater resistance or resilience to disturbances (Nakamura 2008; Tilman and Downing 1994).

Diversity favors productivity because the coexistence of several species leads to functional complementarity and facilitation, which enable the sharing of resources, the mitigation of severe environmental effects and the supply of resources from one species to another (Nakamura 2008). The negative effects of competition, which can lead to lower productivity in some species, are offset by complementarity and/or facilitation, enabling greater productivity at the community level (Lehman and Tilman 2000). Therefore it is expected that in agroforestry systems (AFS) where annual crops are associated with trees and/or animals, productivity is enhanced by diversity, since it will lead to a better use of agroecosystem components in time and space (Nair 1993).

AFS can be defined as associations of several annual or perennial crop species with trees (Somarriba 1992). Several AFS models have been adopted around the world and the diversity within these systems can vary considerably. Souza et al. (2012) studied AFS which include native Mata Atlântica trees, and concluded that these diversified systems favour biodiversity while producing coffee. Several other studies evaluated diversity in AFS, including Anglaaere et al. (2011), Assogbadjo et al. (2012) and Bhagwat et al. (2008). Others studied the productivity of crops in AFS (Deheuvels et al. 2012; Singh et al. 2007; Ogol et al. 1999). However, there is a lack of studies which evaluate total AFS biomass production including tree biomass, and its relationship to the diversity in these systems. Such studies could shed light on ecological factors which link diversity to agroecosystem functions (Smith et al. 2008), and favour the adoption of agricultural systems which serve as biodiversity reservoirs (Vandermeer and Perfecto 2007).

Araújo Filho and Carvalho (2001) propose AFS as an alternative to conventional cropping systems used in Brazil's semiarid region. The production of grain integrated with raising goats or sheep can help maintain areas under natural vegetation and allow the preservation of tree species in the region (Campanha et al. 2011). Traditional cropping practices lead to great losses in biodiversity, since they are characterized by deforestation and the burning of all vegetation, followed by cultivation for two or three consecutive years. After the third year, the area is left fallow for approximately ten years, usually with animal grazing (Araújo Filho 2002). Some studies have compared the AFS proposed by Araújo Filho and Carvalho (2001) to traditional cropping models, and showed the AFS had beneficial effects on soil quality (Aguiar et al. 2010; Maia et al. 2006, 2007, 2008; Nogueira et al. 2008; Silva et al. 2011). However, it is not yet known how the diversity of these systems impacts biomass production in plant communities. It is expected that more diverse agroecosystems will foster greater productivity.

With this in mind, the objectives of the study were: (i) to evaluate plant diversity and productivity in two AFS, a traditional monoculture system, two areas which had been under fallow for six and nine years, respectively, and an area under unmanaged native caatinga vegetation; (ii) to assess the influence of diversity (species richness, Shannon and Pielou indices) on the productivity of the trees/shrub and herbaceous plant communities of these systems; and (iii) to evaluate the effect of diversity on biomass production by Cordia oncocalyx.

\section{Materials and methods}

Study area

The study was conducted at Crioula Farm, within the National Caprine and Ovine Research Center (CNPCO) 
of EMBRAPA in Sobral, Ceará State, Brazil $\left(3^{\circ} 41^{\prime} \mathrm{S}\right.$, $40^{\circ} 20^{\prime} \mathrm{W}$ ). Annual average temperature and rainfall for the Sobral area are $27{ }^{\circ} \mathrm{C}$ and $821 \mathrm{~mm}$, respectively (IPECE 2011). In the experimental area, average annual rainfall over the last 10 years was $989 \mathrm{~mm}$, distributed mainly between the months of January and June. However, $67 \%$ of this rainfall occurs between the months of February and April. The climate, according to Köppen's classification, is dry equatorial tropical, very hot and semiarid (BSW'h) (BRASIL 1981). The soil in the area consists of patches of typic Ortic Chromic Luvisol and typic Ortic Hypo-chromic Luvisol (Aguiar et al. 2010). Vegetation is composed of a deciduous thorny savanna, locally known as caatinga (Cole 1960).

In 1997, a long term experiment was established at Crioula Farm to study AFS as sustainable production systems and alternatives to traditional cropping systems in the region (Araújo Filho and Carvalho 2001). The experiment compares the following management systems: agrosilvopastoral (ASP), where corn and sorghum are grown between alleys of Leucaena or Gliricidia which are used as protein banks for goats and sheep; silvopastoral (SP), which consists of pasture for goats and sheep with native caatinga trees that were pruned and thinned to improve the growth of herbaceous species; traditional cropping (AG), under monocropped corn and sorghum; plots under fallow for six (F6) and nine (F9) years after traditional cropping of corn in monoculture; and caatinga (CAT) which represents natural vegetation in a legally preserved area. These systems and their management history are described in Table 1, and the soil in each system is characterized in Table 2 . All studied systems are adjacent to each other, and separated by alleys approximately $1.5 \mathrm{~m}$ wide (Fig. 1).

\section{Plant diversity}

The plot method was used to evaluate plant diversity (Mueller-Dombois and Ellenberg 1974). Ten plots were randomly delimited in ASP, SP and CAT, and seven plots in AG, F6 and F9 (Fig. 1). In order to assess the tree/woody shrub stratum, plots measuring $10 \times 10 \mathrm{~m}\left(100 \mathrm{~m}^{2}\right)$ were used. The herbaceous stratum was studied in subplots measuring $1 \times 1 \mathrm{~m}$ $\left(1 \mathrm{~m}^{2}\right)$, located inside the $100 \mathrm{~m}^{2}$ plots. Trees and woody shrubs included plants with a circumference at ground level $\geq 9 \mathrm{~cm}$ and height of $1 \mathrm{~m}$ or more. The herbaceous stratum consisted of all plants shorter than
$1 \mathrm{~m}$, with a green stem and poorly or not lignified aerial parts (Rodal et al. 1992). All plants meeting the above-mentioned criteria were counted and identified. Plants with tillers were considered as one individual whenever they had a common base at or above soil level (Rodal et al. 1992).

In order to assess diversity, the following indicators were used: species richness (S) which is a quantification of the number of species present in each area, Pielou's index $\left(\mathrm{J}^{\prime}\right)$ which illustrates the distribution of individuals within species, and Shannon's index $\left(\mathrm{H}^{\prime}\right)$, which considers species richness and relative abundance (Magurran 2004). Species richness was obtained as the sum of all species present in the plots. Shannon's and Pielou's indices were calculated using Eqs. 1 and 3, respectively. Initially, the indices were calculated separately for the tree/woody shrub and herbaceous strata. The same indices were then calculated using the sum of all individuals and species found, with the purpose of obtaining total plant diversity of the systems.

$H^{\prime}=-\sum_{e=1}^{S} p e \times \operatorname{In}(p e)$

$p e=\frac{n e}{N}$

where $H^{\prime}$ is Shannon's index, $p$ e is a species' relative abundance as obtained in Eq. 2, ne is the number of individuals of a given species, $N$ is the total number of individuals, $\mathrm{S}$ is the total number of species and $\mathrm{In}$ is the natural $\log$.

$J^{\prime}=\frac{H^{\prime}}{\log S}$

where $\mathrm{J}^{\prime}$ is Pielou's index, $H^{\prime}$ is Shannon's index and $S$ is the total number of species.

Biomass production

The aboveground biomass produced by tree/woody shrub species was evaluated using allometric equations and diameter at breast height (DBH, $1.3 \mathrm{~m}$ above the ground) data (Silva and Sampaio 2008). The diameter at breast height of all individuals present in the $100 \mathrm{~m}^{2}$ plots described above was measured at the beginning (January) and end (August) of the rainy periods of 2010 and 2011, for a total of four measurements. Tree biomass was estimated using the equations proposed by Silva and Sampaio (2008): 
Table 1 Description of agroforestry systems, the traditional cropping system, fallow areas and unmanaged native vegetation

\begin{tabular}{ll}
\hline $\begin{array}{l}\text { Experimental } \\
\text { areas (area) }\end{array}$ & Cropping system \\
\hline $\begin{array}{l}\text { Agrosilvopastoral } \\
\text { (ASP) }\end{array}$ & $\begin{array}{l}\text { Corn (Zea mays L.) and sorghum (Sorghum bicolor L.) } \\
\text { cropping during the rainy season within rows of } \\
\text { (3.5 ha) }\end{array}$ \\
& $\begin{array}{l}\text { Leucaena leucocephala (Lam) R. of Wit. and } \\
\text { (Leucaena and Gliricidia) are maintained as small } \\
\text { shrubs by pruning twice a year. During the dry } \\
\text { season, the area is used as a protein bank for sheep } \\
\text { (22) and goats (17), which are given access to the } \\
\text { area for one hour each day. }\end{array}$
\end{tabular}

Silvopastoral (SP) Native pasture for a herd of 20 goats and 20 sheep, (5.2 ha) divided for each species.

Traditional
cultivation (AG)
(1.0 ha)

Corn and sorghum monoculture during the rainy season of 2010 .

Six year fallow following AG (F6)

(1.0 ha)

Nine year fallow following $\mathrm{AG}$ (F9)

(1.0 ha)

Native vegetation (CAT)

(1.2 ha)

Corn (Zea mays L.) and bean (Vigna unguiculata L. Walp) cropping during the rainy seasons of 2002 and 2003 , followed by grazing by 10 goats during the dry season.

Annual crop of corn and beans during the rainy seasons of 2000 and 2001, followed by grazing by 10 goats during the dry season.
History and management

\begin{abstract}
In 1997, native vegetation was pruned and thinned, with $20 \%$ of the tree cover (200 trees ha ${ }^{-1}$ ) preserved. Rows of Leucaena were planted every $3 \mathrm{~m}$, perpendicular to the predominant slope. In 2005, part of the Leucaena were substituted for Gliricidia and sorghum cultivation began.

Herbaceous vegetation weeding is done by manual hoeing. Manure harvested in a corral is used to fertilize this area. The plot is sub-divided into two areas for goats and sheep.
\end{abstract}

In 1997 woody vegetation was pruned and thinned, preserving approximately $38 \%$ of the tree cover (260 trees ha-1). Tree regrowth is pruned annually.

In 2009 (end of the dry season), the area was cleared and burned. At the onset of the 2010 rainy season, the soil was manually prepared with a hoe and crops were sown.

Slash and burn of all vegetation in 2001, manual soil preparation and planting of corn and beans in 2002 and 2003. In both years, after harvest, a herd of 10 goats had access to the area in order to consume crop residue, and starting in 2004 the area was left fallow, allowing for the regeneration of native vegetation.

Slash and burn of all vegetation in 1999, manual soil preparation and planting of corn and beans in 2000 and 2001. During both years, after harvest, a herd of 10 goats had access to the area in order to consume crop residue, and starting in 2002, the area was left fallow, allowing for the regeneration of native vegetation.

Natural unmanaged vegetation considered to represent equilibrium-state caatinga, however with some human intervention due to the felling of a small number of trees prior to 1981 and grazing taking place at the end of the dry season and onset of the rainy season.
$\mathrm{B}=0.2368 \mathrm{DBH}^{2.219}$ (for large sized species) and $\mathrm{B}=0.2627 \mathrm{DBH}^{1.9010}$ (for small sized species), where $\mathrm{B}=$ biomass $(\mathrm{kg})$ and $\mathrm{DBH}=$ diameter at breast height $(\mathrm{cm})$. Total biomass accumulated in the plots was obtained by summing the biomass of all plants sampled, and biomass production over each period was calculated as the difference in standing biomass between two time points.

Aboveground herbaceous biomass was obtained by harvesting all plants within a $1 \mathrm{~m}^{2}$ frame, at ground level. The frame was placed at one of the extremities of the $100 \mathrm{~m}^{2}$ plots. The collected material was dried in an oven at $65{ }^{\circ} \mathrm{C}$ for $72 \mathrm{~h}$ and weighed to obtain total dry biomass produced during the evaluation period. Harvesting of herbaceous biomass took place during the rainy periods of 2010 and 2011.

\section{Statistical analysis}

For data analysis, plots were considered to represent samples of the population covering the area under each land use. Land use areas were compared with each other using an analysis of variance followed by Tukey's test at $\alpha=0.05$ (Martins and Santos 1999).

Linear regressions are appropriate to assess the relationship between an explanatory and a dependent 
Table 2 Characterization of the soil (0-0.2 $\mathrm{m}$ depth increment) under various land use systems

\begin{tabular}{|c|c|c|c|c|c|c|}
\hline & ASP & SP & $\mathrm{AG}$ & F6 & F9 & CAT \\
\hline Sand $\left(\mathrm{g} \mathrm{kg}^{-1}\right)$ & 633.0 & 557.0 & 610.0 & 463.0 & 573.0 & 537.0 \\
\hline Silt $\left(\mathrm{g} \mathrm{kg}^{-1}\right)$ & 173.0 & 200.0 & 183.0 & 207.0 & 240.0 & 203.0 \\
\hline Clay $\left(\mathrm{g} \mathrm{kg}^{-1}\right)$ & 193.0 & 243.0 & 207.0 & 330.0 & 187.0 & 260.0 \\
\hline $\mathrm{BD}\left(\mathrm{g} \mathrm{cm}^{-3}\right)$ & 1.3 & 1.2 & 1.2 & 1.1 & 1.3 & 1.1 \\
\hline TOC $\left(\mathrm{g} \mathrm{kg}^{-1}\right)$ & 11.3 & 21.7 & 14.7 & 17.2 & 15.7 & 16.5 \\
\hline $\begin{array}{l}\text { Total N } \\
\qquad\left(\mathrm{g} \mathrm{kg}^{-1}\right)\end{array}$ & 1.1 & 1.6 & 1.2 & 1.4 & 1.2 & 1.5 \\
\hline $\begin{array}{l}\text { Available P } \\
\quad\left(\mathrm{mg} \mathrm{dm}^{-3}\right)\end{array}$ & 14.7 & 3.7 & 10.6 & 11.7 & 2.4 & 3.4 \\
\hline $\mathrm{pH}$ in water & 6.8 & 6.4 & 6.9 & 6.7 & 6.2 & 6.5 \\
\hline $\begin{array}{l}\mathrm{CEC}\left(\mathrm{cmol}_{\mathrm{c}}\right. \\
\left.\mathrm{dm}^{-3}\right)\end{array}$ & 10.7 & 11.4 & 12.6 & 22.1 & 8.5 & 15.2 \\
\hline $\mathrm{V}(\%)$ & 91.5 & 79.6 & 87.8 & 93.8 & 74.4 & 87.0 \\
\hline
\end{tabular}

$B D$ bulk density, $T O C$ total organic carbon, $V$ saturation bases, $A S P$ agrosilvopastoral system, $S P$ silvopastoral system, $A G$ traditional cropping, $F 6$ six year fallow after traditional cropping, F9 nine year fallow after traditional cropping, $C A T$ unmanaged caatinga vegetation, $C E C$ cation exchange capacity

variable (Gotelli and Ellison 2004). Therefore, a linear regression was used to assess whether aboveground biomass production is dependent upon plant diversity. Here diversity was the explanatory variable and was represented by $\mathrm{H}^{\prime}$ and $\mathrm{S}$. Other factors can also influence aboveground biomass production in plant communities, including the density of individuals since it affects competition for resources (Tilman and Lehman 2005). As such, we also evaluated the effect of plant density on community productivity. The response of specific species can be distinct from that of communities, and can vary with the growth stage of individual plants. The influence of community diversity, density and developmental stage of Cordia oncocalyx on its aboveground biomass production was thus evaluated. This species is the most common in all land uses. The developmental stage of $C$. oncocalyx was determined by measuring $\mathrm{DBH}$, assuming that DBH increased with plant age.

\section{Results}

Plant diversity

Average tree/woody shrub species richness was greatest in F6, followed by F9 and CAT (Table 3). AFS

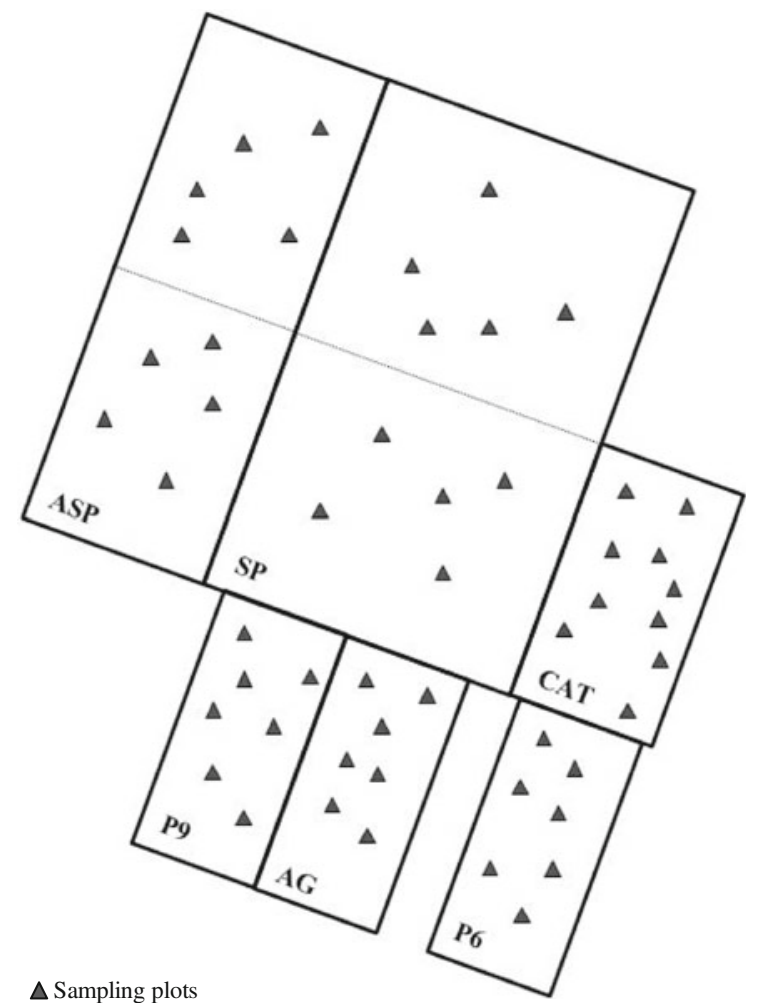

Fig. 1 Diagram of studied agroecosystems. Triangles represents the plots where plant aboveground biomass and diversity was assessed. ASP agrosilvopastoral system, $S P$ silvopastoral system, $A G$ conventional cropping, $F 6$ six year fallow following AG, F9 nine year fallow following AG, CAT unmanaged natural caatinga vegetation

(ASP and SP) had the lowest species richness, due to agricultural and pastoral management. SP, AG and F6 areas had greater species richness in the herbaceous stratum. Species richness in the area under fallow for nine years (F9) was similar to that in CAT. The ASP plot had the lowest number of herbaceous species. However, when considering total species richness (herbaceous + tree/woody shrub + crop species), plots SP, AG, F9 and CAT are similar. Values for these plots were between those for F6, which was the most species rich, and ASP, which was the most species poor. However, considering all plots $\left(1,000 \mathrm{~m}^{2}\right)$, the number of species in ASP is similar to that of CAT, while SP had three fewer tree/woody shrub species and six more herbaceous species than CAT (Table 3).

Shannon's index $\left(\mathrm{H}^{\prime}\right)$ was smaller for the herbaceous stratum of the ASP plot when compared to CAT and the fallow (F6 and F9) and cultivated (AG) plots 
Table 3 Diversity indices for various land use systems at Sobral (CE) in 2010

\begin{tabular}{|c|c|c|c|c|c|c|c|}
\hline \multirow[t]{2}{*}{ Indice } & \multirow[t]{2}{*}{ Strata } & \multicolumn{6}{|c|}{ Systems } \\
\hline & & ASP & SP & $\mathrm{AG}$ & F6 & F9 & CAT \\
\hline \multirow[t]{4}{*}{ Average species richness $\left(\mathrm{S}\right.$; number of species per $100 \mathrm{~m}^{2}$ ) } & Tree & $1.8^{\mathrm{d}}$ & $1.1^{\mathrm{c}, \mathrm{d}}$ & $0.0^{\mathrm{e}}$ & $8.6^{\mathrm{a}}$ & $6.0^{\mathrm{b}}$ & $3.7^{\mathrm{c}}$ \\
\hline & Herb. & $4.1^{\mathrm{d}}$ & $12.2^{\mathrm{a}}$ & $10.0^{\mathrm{a}, \mathrm{b}}$ & $11.3^{\mathrm{ab}}$ & $7.7^{\mathrm{c}}$ & $8.5^{\mathrm{b}, \mathrm{c}}$ \\
\hline & Crops & 3.8 & 0.0 & 2.0 & 0.0 & 0.0 & 0.0 \\
\hline & Total & $9.7^{\mathrm{c}}$ & $13.3^{\mathrm{b}}$ & $11.3^{\mathrm{b}, \mathrm{c}}$ & $19.9^{\mathrm{a}}$ & $13.7^{\mathrm{b}}$ & $12.2^{\mathrm{b}}$ \\
\hline \multirow[t]{2}{*}{ Species richness $\left(\mathrm{S}\right.$; number of species per $\left.1,000 \mathrm{~m}^{2}\right)$} & Tree & 8.0 & 5.0 & 0.0 & 12.0 & 12.0 & 8.0 \\
\hline & Herb. & 9.0 & 19.0 & 19.0 & 17.0 & 13.0 & 12.0 \\
\hline \multirow[t]{3}{*}{ Average Shannon's index $\left(\mathrm{H}^{\prime}\right.$; nats ind $\left.{ }^{-1}\right)$} & Tree & $0.51^{\mathrm{b}}$ & $0.07^{\mathrm{b}}$ & - & $1.77^{\mathrm{a}}$ & $1.56^{\mathrm{a}}$ & $0.95^{\mathrm{b}}$ \\
\hline & Herb. & $0.99^{\mathrm{c}}$ & $1.31^{\mathrm{b}}$ & $1.59^{\mathrm{a}, \mathrm{b}}$ & $1.62^{\mathrm{a}, \mathrm{b}}$ & $1.86^{\mathrm{a}}$ & $1.53^{\mathrm{b}}$ \\
\hline & Total & $1.03^{\mathrm{c}, \mathrm{d}}$ & $0.78^{\mathrm{d}}$ & $0.91^{\mathrm{cd}}$ & $1.56^{\mathrm{a}, \mathrm{b}}$ & $1.85^{\mathrm{a}}$ & $1.27^{\mathrm{b}, \mathrm{c}}$ \\
\hline \multirow[t]{3}{*}{ Average Pielou's index $\left(\mathrm{J}^{\prime}\right)$} & Tree & $0.97^{\mathrm{a}}$ & $0.92^{\mathrm{a}, \mathrm{b}}$ & - & $0.83^{\mathrm{b}}$ & $0.83^{\mathrm{a}, \mathrm{b}}$ & $0.76^{\mathrm{b}}$ \\
\hline & Herb. & $0.59^{\mathrm{c}, \mathrm{d}}$ & $0.53^{\mathrm{d}}$ & $0.71^{\mathrm{b}, \mathrm{c}}$ & $0.67^{\mathrm{b}, \mathrm{c}}$ & $0.85^{\mathrm{a}}$ & $0.73^{\mathrm{a}, \mathrm{b}}$ \\
\hline & Total & $0.73^{\mathrm{a}, \mathrm{b}}$ & $0.53^{\mathrm{c}}$ & $0.69^{\mathrm{b}}$ & $0.74^{\mathrm{a}, \mathrm{b}}$ & $0.85^{\mathrm{a}}$ & $0.74^{\mathrm{a}, \mathrm{b}}$ \\
\hline
\end{tabular}

Values followed by identical letters, in lines, do not differ significantly based on Tukey's test at a probability level of 0.05

$A S P$ agrosilvopastoral system, $S P$ silvopastoral system, $A G$ traditional cropping system, $F 6$ six year fallow after traditional cropping, F9 nine year fallow after traditional cropping, CAT unmanaged caatinga vegetation. Tree tree/woody shrub stratum, Herb. herbaceous stratum

(Table 3). Diversity in the SP plot was similar to that of CAT, AG and F6, and superior to ASP. In the tree/ woody shrub stratum, AFS (ASP and SP) maintained a diversity similar to that of preserved native vegetation (CAT), but diversity was inferior to fallow areas (F6 and F9). The ASP plot's total diversity was similar to that of CAT, but lower than in the fallow areas (F6 and F9). On the other hand, total diversity in the SP plot was not similar to that of CAT (Table 3).

Despite the lower number of species and low Shannon diversity, the ASP system displayed high uniformity as given by Pielou's index, similar to SP and F9 and above F6 and CAT, which indicates an even distribution of individuals among species (Table 3).

\section{Aboveground biomass}

At the last sampling date, unmanaged vegetation (CAT) had accumulated $120 \pm 45 \mathrm{t} \mathrm{ha}^{-1}$ of tree/ woody shrub biomass. The ASP and SP plots accumulated, respectively, 20 and $15 \%$ of the tree/ woody shrub biomass accumulated by CAT, while F6 accumulated $32 \%$ and F9 $41 \%$, in relation to CAT (Fig. 2a). Biomass in the ASP and SP plots increased by 3 tons over the study period (Jan 2010-Aug 2011), whereas in fallow areas (F6 and F9) and CAT the increase was 9 tons. The average annual rate of tree/ woody shrub biomass production is equivalent to 1.6 $\mathrm{t} \mathrm{ha}^{-1} \mathrm{yr}^{-1}$ for ASP and SP, which is less than values observed in the fallow areas and CAT (4.8, 4.4 and 5.4 $\mathrm{t} \mathrm{ha}^{-1} \mathrm{yr}^{-1}$ for $\mathrm{F} 6, \mathrm{~F} 9$ and CAT, respectively) (Fig. 2b). However, productivity in terms of percentage for the tree/woody shrub stratum in SP was similar to that observed in F6 and F9, while biomass increase in the ASP system was proportional to that in CAT (Fig. 2b).

In general, plots with little or no tree cover (ASP, SP and AG) were those which produced the greatest amount of herbaceous biomass (Fig. 2c). The greatest amounts of herbaceous biomass were observed in AG and SP in 2010, and in ASP and SP in 2011. In these two years, the smallest amount of herbaceous biomass was observed in F9, followed by CAT.

Total aboveground biomass (tree/woody shrub + herbaceous + crop) produced over the study period in the ASP plot was similar to that in the F6, F9 and CAT plots (Fig. 2d). Total biomass in the SP and AG plots had average values inferior to those in ASP, F6 and CAT, and similar to F9. The production of corn and sorghum crops in the ASP plot amounted to $3.6 \mathrm{t} \mathrm{ha}^{-1}$, whereas production of corn and sorghum crops in the AG plot was $3.0 \mathrm{t} \mathrm{ha}^{-1}$. It is noteworthy that the ASP system was in its 13th year of consecutive cultivation, while the AG system had been cropped for only two years. 


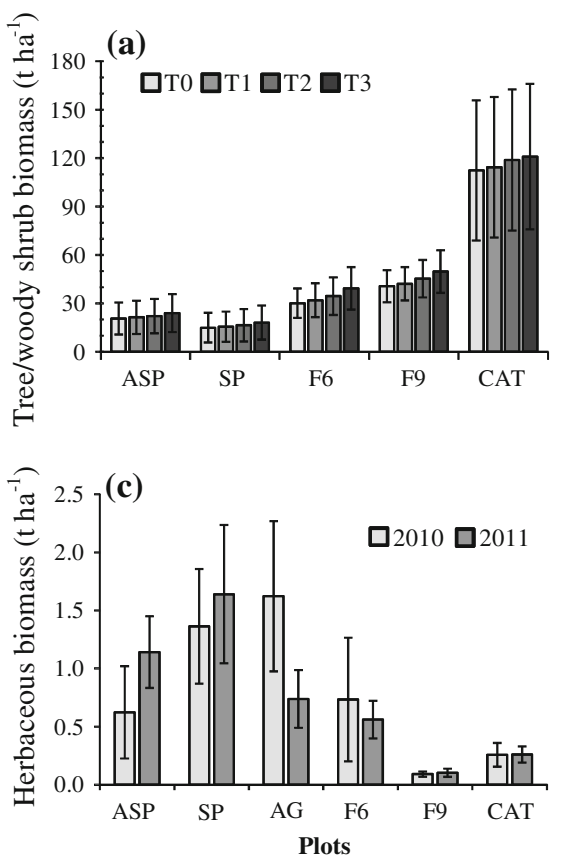

Fig. 2 a Tree/woody shrub biomass accumulated during the study period; TO January 2010, T1 August 2010, T2 January 2011, T3 August 2012; b gross tree/woody shrub biomass production rate and relative biomass production (percent increase) during the period from January 2010 to August 2012; c herbaceous biomass observed in 2010 and 2011; d total

Biomass in relation to diversity

A linear relationship was found between diversity and tree/woody shrub biomass production (Fig. 3a, b), indicating a positive relationship exists between aboveground biomass production and diversity. However, the $\mathrm{R}^{2}$ value for this relationship is low. Significance was also weak for the relationship between density of tree/ woody shrub individuals and productivity (Fig. 3c), with a lower $\mathrm{R}^{2}$ than that observed for diversity.

In the herbaceous stratum, no relationship was observed between biomass and $\mathrm{H}^{\prime}$, only a positive trend between $\mathrm{S}$ and biomass production (Fig. $4 \mathrm{a}, \mathrm{b}$ ). There are indications that the density of individuals positively impacts biomass production (Fig. 4c), since the relationships were significant although $\mathrm{R}^{2}$ was low (Fig. 4). In this stratum, a greater density of individual plants allows a better use of resources such as light, favoring greater priduction as observed in SP and AG (Fig. 2e).

No influence of total diversity on total biomass production was observed (Fig. 5a, b). However, a
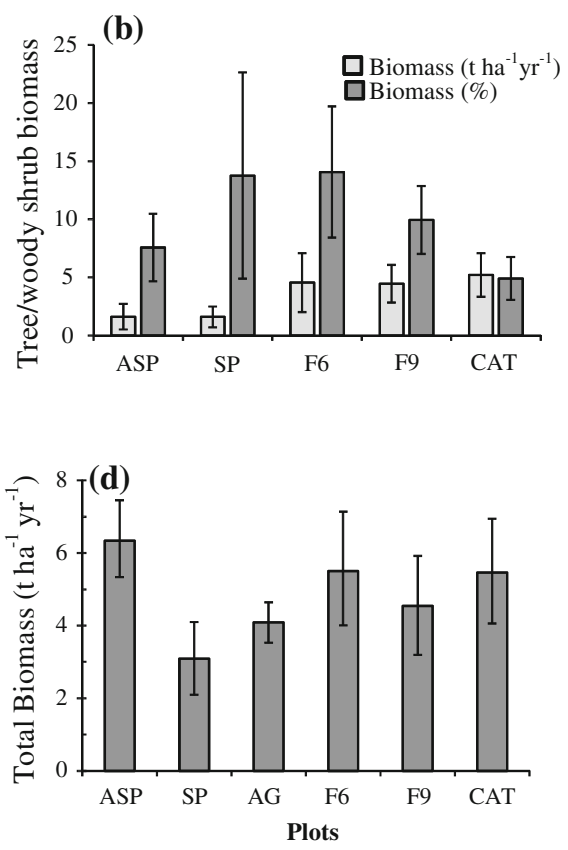

biomass produced. $A S P$ agrosilvopastoral system, $S P$ silvopastoral system, $A G$ conventional cropping, $F 6$ six year fallow following AG, F9 nine year fallow following $\mathrm{AG}, C A T$ unmanaged natural caatinga vegetation. Vertical bars represent standard deviation of the mean

negative linear relationship between plant density and biomass production was found (Fig. 5c) indicating that plots where plant density was lower had greater biomass production. The greatest plant densities result from greater numbers of herbaceous plants, and occur where there are fewer trees. Trees produce more aboveground biomass than herbaceous plants, and as such total biomass increases as total plant density decreases.

Biomass production by $C$. oncocalyx was not affected by Shannon's diversity index (Fig. 6a), however a tendency for aboveground biomass to decrease as the number of species in the community increases was observed (Fig. 6b). The relationship of $\mathrm{H}^{\prime}$ and $\mathrm{S}$ with C. oncocalyx aboveground biomass was significant, but with low regression coefficients (Fig. 6). Greater density of tree/woody shrub individuals was found to negatively influence biomass production of $C$. oncoca$l y x$. A good fit was obtained for the relationship between the diameter of $C$. oncocalyx and the biomass of individual trees, which indicates that the developmental stage of this plant influences its production of biomass. 

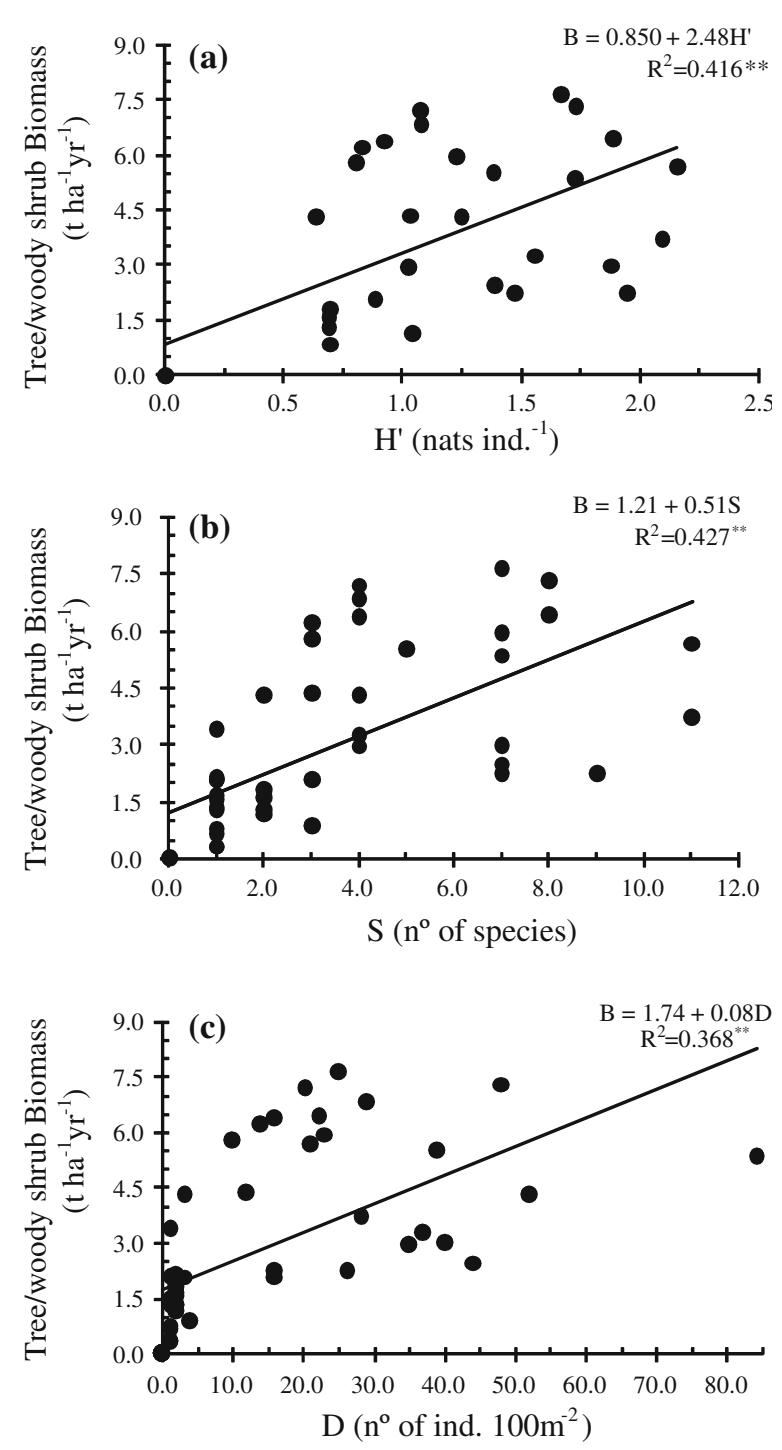

Fig. 3 Tree/woody shrub biomass production (B) in response to a Shannon's diversity index $\left(\mathrm{H}^{\prime}\right)$; b species richness $(\mathrm{S})$, and c the density of individuals (D) ** $p \leq 0.01$

\section{Discussion}

Plant diversity

The lowest diversity was observed in AFS, and is due to dominance by a few species. During site preparation the vegetation in the plots was thinned and all species originally present in the area were preserved, but their densities were reduced proportionally to their initial density. Thus, the dominant tree species in ASP and SP, C. oncocalyx, is also dominant in CAT and fallow areas. Diversity in AFS is reduced due to the low
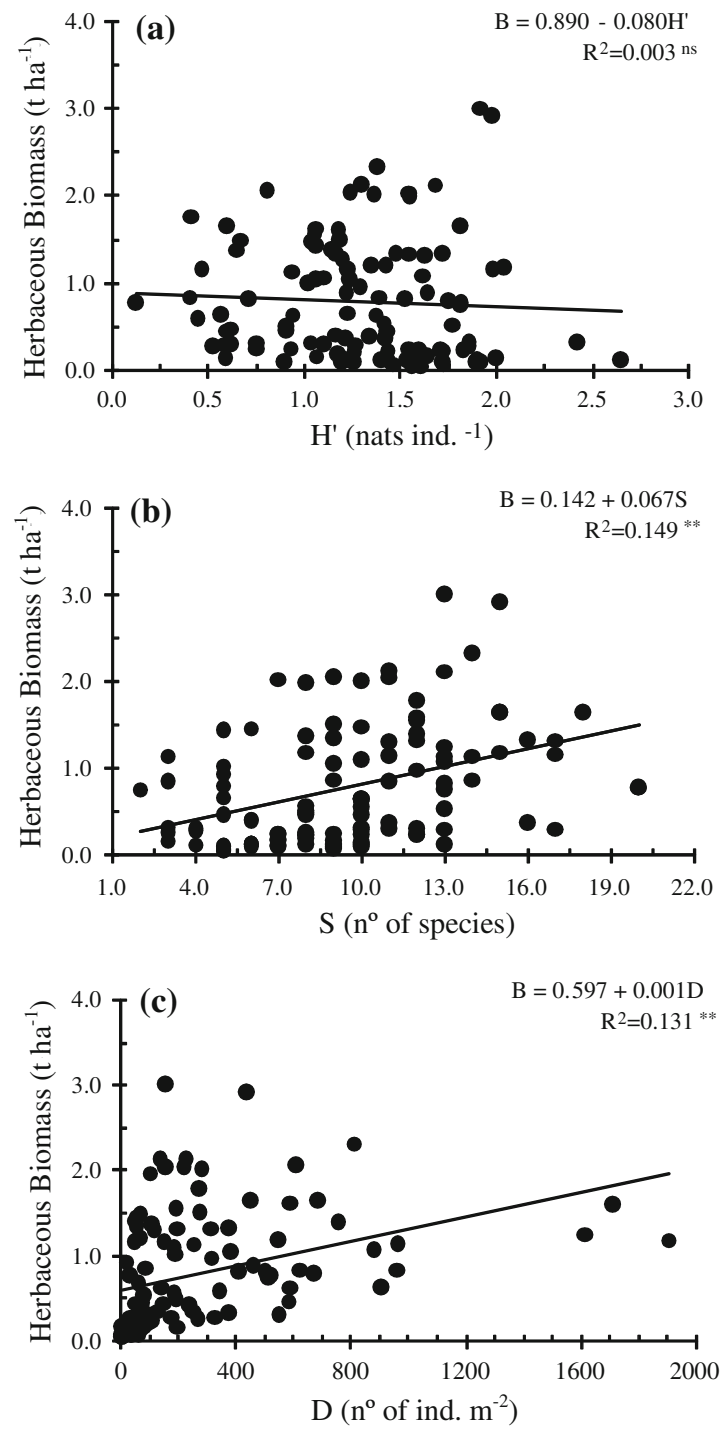

Fig. 4 Herbaceous biomass production (B) in response to a Shannon's diversity index $\left(\mathrm{H}^{\prime}\right)$; b species richness $(\mathrm{S})$, and c the density of individuals (D) ** $p \leq 0.01$; $p \leq 0.05$; $n s$ not significant

number of species sampled per plot $\left(100 \mathrm{~m}^{2}\right)$, which reflects the thinning imposed on these areas. In addition, the herbaceous stratum in ASP is largely influenced by hoeing, which reduces diversity and species richness. However, species richness is offset by the introduction of agricultural species (corn, sorghum, Leucaena and Gliricidia). Leucaena and Gliricidia, both of which are legumes, are key components for the sustainability of agroecosystems. Indeed, not only are they used as animal feed but 

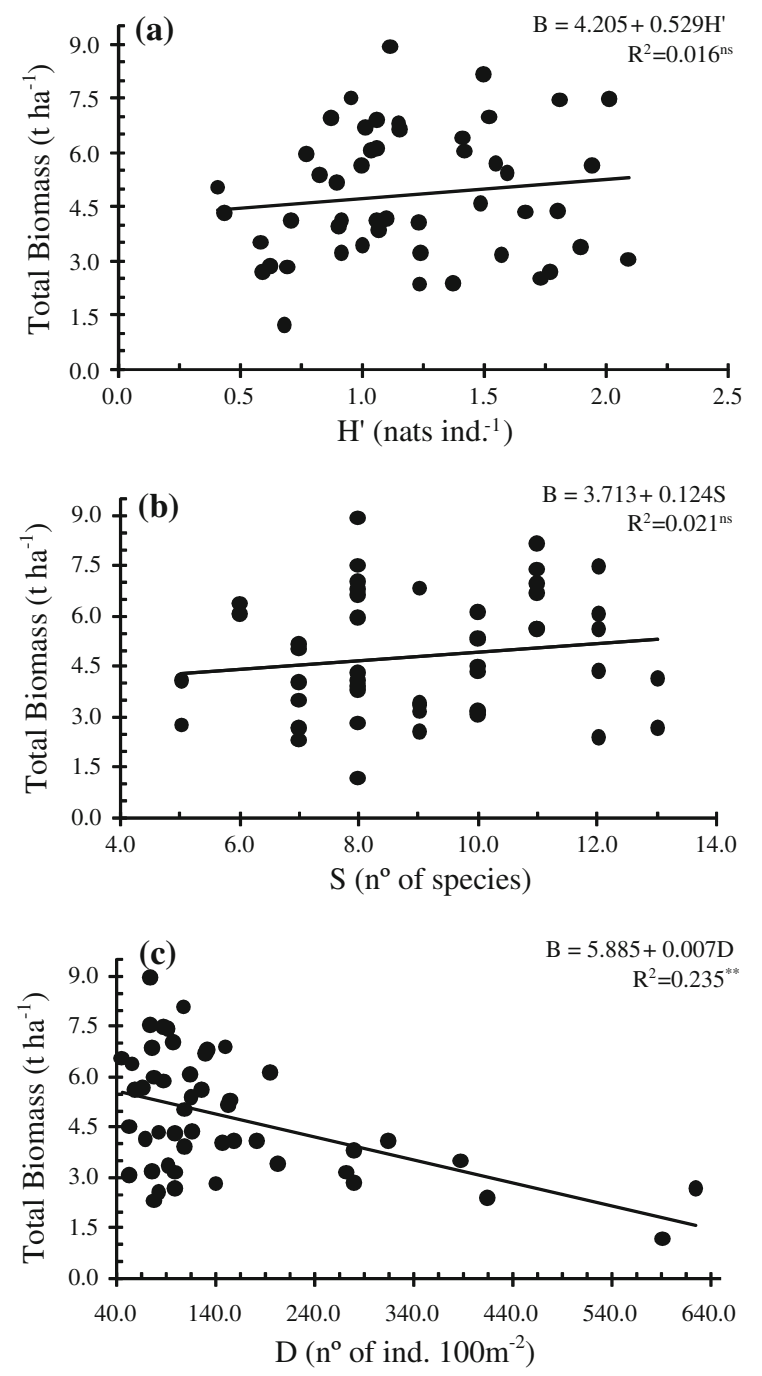

Fig. 5 Total biomass production (B) in response to a Shannon's diversity index $\left(\mathrm{H}^{\prime}\right)$; b species richness $(\mathrm{S})$, and $\mathbf{c}$ the density of individuals (D) $* * p \leq 0.01 ; * p \leq 0.05$; $n s$ not significant

they are also capable of biological nitrogen fixation (Paulino et al. 2009), they provide organic matter inputs into the soil (Maia et al. 2007) and they contribute to reduce soil erosion (Aguiar et al. 2010). However, care must be taken in order to avoid the invasion of unmanaged areas by these species (Rejmanek and Richardson 1996), which could be detrimental to local biodiversity.

Shannon's diversity indices in the ASP system are similar to those observed by Almeida et al. (2009) in caatinga areas under agroforestry management. However, unlike what was observed in this study, Almeida et al. (2009) found greater tree species richness in cultivated areas as opposed to unmanaged areas. Such greater richness was explained by the introduction of fruit species in cultivated areas.

The greater diversity $\left(\mathrm{S}\right.$ and $\left.\mathrm{H}^{\prime}\right)$ and uniformity $\left(\mathrm{J}^{\prime}\right)$ observed in fallow areas is due to the greater species richness and diversity than is usually observed in areas under secondary succession, as reported by Anglaaere et al. (2011) in areas recently impacted by fire. This occurs because, initially, newly disturbed areas can be colonized by species from adjacent areas where vegetation was preserved, as noted by Almeida et al. (2009). As the ecosystem stabilizes, ecological niches become well defined. Competitively superior species remain and become more abundant (Libano and Felfili 2006). Therefore, in CAT where the plant community is more stable, diversity and species richness are lower than in fallow areas. Mani and Parthasarathy (2009) also noted reduced diversity of trees, with loss of some species in older forests, but attributed the changes to the cumulative effects of habitat quality, human activities and changes in usage patterns of adjacent areas. The greater diversity found in F6 and F9 when compared to CAT is in agreement with the intermediate disturbance hypothesis (Connell 1978), which states that tree diversity is greater when a system has not yet reached equilibrium. Studies carried out in other dryland forests after different fallow lengths have obtained contradicting results. Kalacska et al. (2004) reported greater species diversity in areas under intermediate secondary succession, while others found that diversity increased together with age (LebrijaTrejos et al. 2008; Ruiz et al. 2005) and that average species richness in areas under fallow was lesser than in mature forest (Lebrija-Trejos et al. 2008).

\section{Aboveground biomass}

The tree/woody shrub biomass accumulated in ASP and SP is below the wide range cited by Cavalcante et al. (2009) for unmanaged caatinga, while biomass accumulation in F6, F9 and CAT falls within the values cited by these authors.

Greater biomass can result from both the productive performance of individual plants, and their density in a given area. Greater productivity of trees/woody shrubs observed in F6, F9 and CAT occurred because plant density was greater in these areas. In ASP and SP trees are more efficient because they are more widely 
Fig. 6 Biomass production of C. oncocalyx (B) in response to a Shannon's diversity index $\left(\mathrm{H}^{\prime}\right)$; b species richness (S), c the density of individuals (D); and $\mathbf{d}$ diameter at breast height $(\mathrm{DBH}) * * p \leq 0.01$; $* p \leq 0.05$; $n s$ not significant

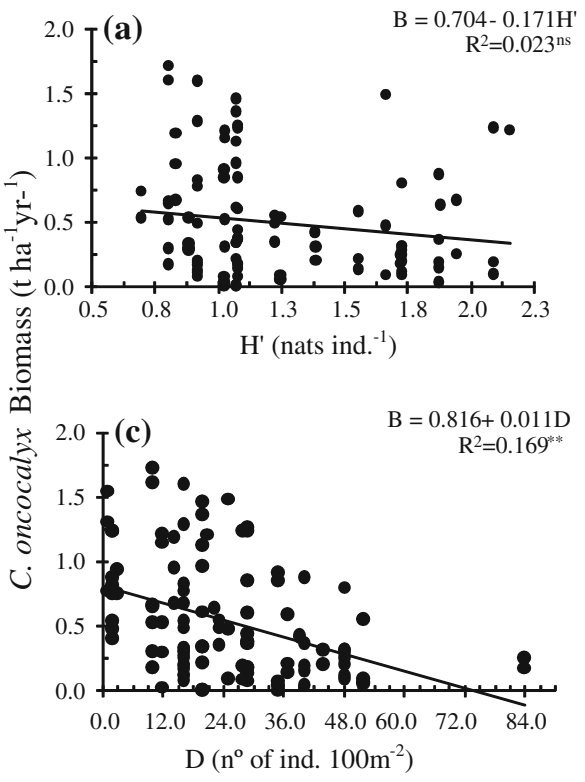

spaced, however the smaller number of individuals results in reduced productivity. The greater productivity of agricultural species (corn and sorghum) in ASP (3.6 $\left.\mathrm{tha}^{-1}\right)$ compared to AG $\left(3.0 \mathrm{t} \mathrm{ha}^{-1}\right)$ indicates the greater efficiency of this management system and the benefits of maintaining diversity in agricultural environments.

Aboveground caatinga biomass in Brazil's semiarid region is quite variable. In the CAT, F6 and F9 plots, aboveground biomass was less than reported by Sampaio et al. (1998) for areas of caatinga after six years of fallow. In the areas under fallow for six and nine years, aboveground biomass was lesser than in CAT despite these areas having the greatest annual growth rate. The greater biomass acumulation in fallow plots is likely due to the greater number of young plants that grow faster than older ones. Also, small species with rapid growth, such as $C$. alliadora and Croton blachetianus, were more frequent in F6 and F9. On the other hand, greater biomass accumulation indicates that fallow periods were insufficient for plots to be restored to a state similar to unmanaged vegetation. Greater biomass accumulation combined with a higher density of tree individuals are considered features of areas that are recuperating after slash and burn (Cavalcante et al. 2009), but which have not yet reached equilibrium.

Greater production of herbaceous biomass in areas managed by humans was observed by Chandrasekaran and Swamy (2002) as well as in ASP, SP and AG in this study, and occurs because of the higher incidence of light and faster nutrient cycling in these areas.

Biomass production in relation to diversity

Greater biomass accumulation in areas with greater diversity indicates the existence of positive relationships between species. Several studies show that the positive effect of diversity on productivity is due to mechanisms of complementarity among species including the efficient use of resources such as water and nutrients, niche partitioning, facilitation and control of herbivores and disease causing agents (Anderson 2005; Cardinale et al. 2002, 2007; Flombaum and Sala 2008; Ruijven and Berendse 2005; Zhu et al. 2000). However, the magnitude of these positive effects varies in different ecosystems and with species involved. In agricultural environments, Smith et al. (2008) indicate that the effect of species diversity on productivity is specific to each species. These authors indicate that the introduction of nitrogen fixing species can lead to improved productivity in more diverse systems, by favoring greater availability of nitrogen in the soil. There is no consensus regarding the net effect of diversity on biomass production. A meta-analysis performed by Cardinale et al. (2007) shows positive effects of plant diversity on biomass production, but some polycultures produced less biomass than certain 
monocultures. Thus, the trend observed here where tree biomass was greater in more diverse environments may be explained by other factors including the dynamics of the successional environments, which remains an understudied concept (Cardinale et al. 2007).

The effects of herbaceous plant diversity on their productivity have not been clarified in other studies. Liu et al. (2010) studied the influence of diversity on the productivity of herbaceous biomass at a regional scale and concluded that the diversity-productivity hypothesis (Tilman et al. 1996; Hooper et al. 2005) was only partially verified. Nakamura (2008) did not observe a positive effect of species richness on the productivity of herbaceous plants, and attributed this to the functional similarity of the species studied. In our study it is likely that the productivity of herbaceous plants was more influenced by the availability of light, since the greatest productivity was observed in areas with little or no tree cover.

Although our results show a trend for greater tree biomass production in areas of greater diversity, real positive effects of diversity on system productivity could not be demonstrated since successional dynamics and the management applied to each plot influenced the results. On the other hand, it is likely that local soil and climate conditions prevent the coexistence of a large number of competitive species, which would allow greater diversity and consequently greater productivity (Lehman and Tilman 2000; Tilman and Pacala 1993; Tilman et al. 2005).

It is expected that, contrarily to the community's biomass which is expected to be greater, the biomass of individual species will decrease in more diverse environments (Lehman and Tilman 2000). Here, biomass production by $C$. oncocalyx was considerably more influenced by its stage of development than by diversity, since larger plants produced more biomass annually.

In environments without anthropogenic disturbances, a positive relationship between diversity and biomass production will only be observed where equilibrium has not been reached or in ecosystems that have suffered a disturbance, since biomass does not change over time in stable communities (Cavalcante et al. 2009; Pimm 1984). Thus, biomass changes observed in F6 and F9 indicate that these plots are undergoing a process of regeneration. In disturbed environments new species may become established, thereby increasing diversity and hence community biomass.

\section{Conclusions}

The type of management applied in AFS ASP and SP changes the diversity and biomass production of plant communities, mainly of plants present in the herbaceous stratum. However, management techniques also maintain some parameters of diversity in the tree/ woody shrub component, similar to the unmanaged vegetation. When agricultural components are taken into consideration, the ASP system was similar to CAT in terms of biomass production and plant diversity.

Fallow periods of six and nine years were sufficient for biomass productivity to reach the level observed in unmanaged vegetation, however they were not sufficient for the same diversity indices to be reached.

Diversity does not influence biomass production in plant communities. Annual biomass production by C. oncocalyx is influenced by the developmental stage of individuals and not by the diversity of the community.

Acknowledgments The authors are grateful to the Conselho Nacional de Pesquisa e Desenvolvimento Científico e Tecnológico (CNPq) for financial support and to the Centro Nacional de Pesquisa de Caprinos e Ovinos of the Empresa Brasileira de Pesquisa Agropecuária (CNPCO-EMBRAPA) for technical and logistical support.

\section{References}

Aguiar MI, Maia SMF, Xavier FAS, Mendonça ES, Araújo Filho JA, Oliveira TS (2010) Sediment, nutrient and water losses by water erosion under agroforestry systems in the semi-arid region in northeastern Brazil. Agrofor Syst 79:277-289

Almeida MVR, Oliveira TS, Bezerra AME (2009) Biodiversidade em sistemas agroecológicos no município de Choró, CE, Brasil. Ciên Rural 39:1080-1087

Anderson RL (2005) Improving sustainability of cropping systems in the Central Great Plaint. J Sustain Agric 26:97-114

Anglaaere LCN, Cobbina J, Sinclair FL, Mcdonald MA (2011) The effect of land use systems on tree diversity: farmer preference and species composition of cocoa-based agroecosystems in Ghana. Agroforest Syst 81:249-265

Araújo Filho JA (2002) Histórico do uso dos solos da caatinga. In: Araújo QR (ed) 500 anos de uso do solo no Brasil. Ilhéus, Editus, pp 329-337

Araújo Filho JA, Carvalho FC (2001) Sistemas de produção agrossilvipastoril para o semi-árido nordestino. In: Carvalho MM, Alvim MJ, Carneito JC (eds) Sistemas agroflorestais pecuários: opções de sustentabilidade para áreas tropicais e sub tropicais. FAO, Brasília, pp 101-110

Assogbadjo AE, Glèlè Kakaï R, Vodouhê FG, Djagoun CAMS, Codjia JTC, Sinsi B (2012) Biodiversity and socioeconomic factors supporting farmers' choice of wild edible 
trees in the agroforestry systems of Benin (West Africa). For Policy Econ 14:41-49

Bhagwat SA, Willis KJ, Birks HJB, Whittaker RJ (2008) Agroforestry: a refuge for tropical biodiversity? Trends Ecol Evol 23:264-267

BRASIL (1981). Ministério das Minas e Energia. RADAMBRASIL. Folhas SB. 24/25-Jaguaribe/Natal 1981. Geologia/Geomorfologia/Pedologia/Vegetação/Uso Potencial da Terra. Rio de Janeiro. (Levantamento de Recursos Naturais)

Campanha MM, Araújo FS, Meneses MOT, Silva VMR, Medeiros HR (2011) Estrutura da comunidade vegetal arbóreo-arbustiva de um sistema agrossilvipastoril, em Sobral, CE. Revista Caatinga 24:94-101

Cardinale BJ, Palmer MA, Collins SL (2002) Species diversity enhances ecosystem functioning through interspecific facilitation. Nature 415:426-429

Cardinale BJ, Wright JP, Cadotte MW, Carroll IT, Hector A, Srivastava DS, Loreau M, Weis JJ (2007) Impacts of plant diversity on biomass production increase through time because of species complementarity. PNAS 104:18123 $-18128$

Cavalcante ADC, Rodal MJN, Sampaio EVSB, Costa KCC (2009) Mudancas floristicas e estruturais, após cinco anos, em uma comunidade de Caatinga no estado de Pernambuco, Brasil. Acta Bot Bras 23:1210-1212

Chandrasekaran S, Swamy PS (2002) Biomass, literfall and aboveground net primary productivity of herbaceous communities in varied ecosystms at Kodayar in the western ghats of Tamil Nadu. Agric Ecosyst Environ 88:61-71

Cole MM (1960) Cerrado, Caatinga and Pantanal: the distribution and origin of the savanna vegetation of Brazil. Geogr J 126:168-179

Connell JH (1978) Diversity in tropical rain forests and coral reefs. Science 199(4335):1302-1310

Deheuvels O, Avelino J, Somarriba E, Malezieuxe E (2012) Vegetation structure and productivity in cocoa-based agroforestry systems in Talamanca, Costa Rica. Agric Ecosyst Environ 149:181-188

Flombaum P, Sala OE (2008) Higher effect of plant species diversity on productivity in natural than artificial ecosystems. PNAS 105:6087-6090

Gotelli NJ, Ellison AM (2004) A primer of ecological statistics. Sinauer Associetes, Sunderland

Hooper DU, Chapin FS, Ewell JJ, Hector A, Inchausti P, Lavorel S, Lawton JH, Lodge DM, Loreau M, Naeem S, Schmid B, Setälä H, Symstad AJ, Vandermeer J, Wardle DA (2005) Effects of biodiversity on ecosystem functioning: a consensus of current knowledge. Ecol Monogr 75:3-35

IPECE-Instituto de Pesquisa e Estratégia Econômica do Ceará (2011) Perfil básico municipal, Sobral. SEPLAN-Secretaria do planejamento e coordenação. Governo do Estado do Ceará, Fortaleza

Kalacska M, Sanchez-Azofeifa GA, Calvo-Alvarado JC, Quesada M, Rivard B, Janzen DH (2004) Species composition, similarity and diversity in three successional stages of a seasonally dry tropical forest. For Ecol Manage 200:227-247

Keer G, Zedler JB (2002) Salt marsh canopy architecture differs with the number and composition of species. Ecol Appl $12: 456-473$
Lebrija-Trejos E, Bongers F, Pérez-García EA, Meave JA (2008) Successional change and resilience of a very dry tropical deciduous forest following shifting agriculture. Biotropica 40:422-431

Lehman CL, Tilman D (2000) Biodiversity, stability, and productivity in competitive communities. Am Nat 156:534 $-552$

Libano AM, Felfili JM (2006) Mudanças temporais na composição florística e na diversidade de um cerrado sensu stricto do Brasil Central em um periodo de 18 anos (1985-2003). Acta Bot Bras 20:927-936

Liu Z, Fu B, Zheng X, Liu G (2010) Plant biomass, soil water content and soil N:P ratio regulating soil microbial functional diversity in a temperate steppe: a regional scale study. Soil Biol Biochem 42:445-450

Magurran AE (2004) Measuring biological diversity. Blackwell Science Ltd., Oxford

Maia SMF, Xavier FAS, Oliveira TS, Mendonça ES, Araújo Filho JA (2006) Impactos de sistemas agroflorestais e convencional sobre a qualidade do solo no semi-árido cearense. Revista Árvore 30:837-848

Maia SMF, Xavier FAS, Oliveira TS, Mendonca ES, Araujo Filho JA (2007) Organic carbon pools in a luvisol under agroforestry and conventional farming systems in the semiarid region of Ceará, Brazil. Agrofor Syst 71:127-138

Maia SMF, Xavier FAS, Oliveira TS, Mendonça ES, Araújo Filho JA (2008) Frações de nitrogênio em Luvissolo sob sistemas agroflorestais e convencional no semi-árido cearense. Revista Brasileira de Ciências do Solo 32:381-392

Mani S, Parthasarathy N (2009) Tree population and abovegraud biomass chages in two disturbed tropical dry evergreen forests of peninsular India. Trop Ecol 50:249-258

Martins FR, Santos FAM (1999) Técnicas usuais de estimative da biodiversidadde. Rev Holos 1(Edição especial): 236-267

Mueller-Dombois D, Ellenberg H (1974) Aims and methods of vegetation ecology. John Wiley \& Sons, New York

Nair PKR (1993) An introduction to agroforestry. Kluwer, Dordrecht

Nakamura N (2008) Species richness and aggregation effects on the productivity of ruderal plant communities under drought perturbation. Biosci Horiz 1:128-135

Nogueira RS, Oliveira TS, Teixeira AS, Araújo Filho JA (2008) Redistribuição de carbono orgânico e fósforo pelo escoamento superficial em sistemas agrícolas convencionais e agroflorestais no semi-árido cearense. Revista Ceres 55: 327-337

Ogol CKPO, Spence JR, Keddie A (1999) Maize stem borer colonization, establishment and crop damage levels in a maize-leucaena agroforestry system in Kenya. Agric Ecosyst Environ 76:1-15

Paulino GM, Alves BJR, Barroso DG, Urquiaga S, Espindola JAA (2009) Fixação biológica e transferência de nitrogênio por leguminosas em pomares orgânicos de mangueira e gravioleira. Pesq Agrop Bras 44:1598-1607

Pimm SL (1984) The complexity and the stability of ecosystems. Nature 307:321-326

Rejmanek M, Richardson DM (1996) What attributes make some plant species more invasive? Ecology 77:1655-1661

Rodal MJNR, Sampaio EVSB, Figueiredo MA (1992) Manual sobre métodos de estudo florístico e fitossociológico: 
ecossistema caatinga. Sociedade Botânica do Brasil, Brasília

Ruijven JV, Berendse F (2005) Diversity-productivity relationships: initial effects, long-term patterns, and underlying mechanisms. PNAS 102:695-700

Ruiz J, Fandiño MC, Chazdon RL (2005) Vegetation structure, composition, and species richness across a 56-year chronosequence of dry tropical forest on Providencia Island, Colombia. Biotropica 37:520-530

Sampaio EVSB, Araujo EL, Salcedo IH, Tiessen H (1998) Regeneração da vegetação de Caatinga após corte e queima, em Serra Talhada, PE. Pesq Agrop Bras 33:621-632

Silva GC, Sampaio EVSB (2008) Biomassas de partes aéreas em plantas da Caatinga. Rev Árv 32:567-575

Silva GL, Lima HV, Campanha MM, Gilkes RJ, Oliveira TS (2011) Soil physical quality of luvisols under agroforestry, natural vegetation and conventional crop management systems in the Brazilian semi-arid region. Geoderma 167-168:61-70

Singh G, Mutha S, Bala N (2007) Effect of tree density on productivity of a Prosopis cineraria agroforestry system in North Western India. J Arid Environ 70:152-163

Smith RG, Gross KL, Robertson GP (2008) Effects of crop diversity on agroecosystem function: crop yield response. Ecosyst 11:355-366

Smukler SM, Sánchez-Moreno S, Fonte SJ, Ferris H, Klonsky K, O'geen AT, Scow KM, Steenwerth KL, Jackson LE (2010) Biodiversity and multiple ecosystem functions in an organic farmscape. Agric Ecosyst Environ 139:80-97

Somarriba E (1992) Revisiting the past: an essay on agroforestry definition. Agrofor Syst 19:233-240
Souza HN, Goede RGM, Brussaard L, Cardoso IM, Duarte EMG, Fernandes BA, Gomes LC, Pulleman MM (2012) Protective shade, tree diversity and soil properties in coffee agroforestry systems in the Atlantic rainforest biome. Agric Ecosyst Environ 146:179-196

Swift MJ, Izac AMN, Van Noordwijk M (2004) Biodiversity and ecosystem services in agricultural landscapes-are we asking the right questions? Agric Ecosyst Environ 104: 113-134

Tilman D, Downing JA (1994) Biosiversity and stability in grasslands. Nature 367:363-365

Tilman D, Pacala S (1993) The maintenance of species richness in plant communities. In: Ricklefs RE, Schluter D (eds) Species diversity in ecological communities. University of Chicago Press, Chicago

Tilman D, Wedin D, Knops J (1996) Productivity and sustainability influenced by biodiversity in grassland ecosystems. Nature 379:718-720

Tilman D, Palosky S, Lehman C (2005) Diversity, productivity and temporal stability in the economies of humans nature. J Environ Econ Manag 49:405-426

Vandermeer J, Perfecto I (2007) The agricultural matrix and a future paradigm for conservation. Conserv Biol 21: 274-277

Wilsey BJ, Potvin C (2000) Biodiversity and ecosystem functioning importance of species evenness in an old field. Ecology 81:887-892

Zhu YY, Chen HR, Fan JH, Wang YY, Li Y, Chen JB, Fan JX, Yang SS, Hu LP, Leung H, Mew TM, Teng OS, Wang ZH, Mundt CC (2000) Genetic diversity and disease control in rice. Nature 406:718-722 